\title{
KARST WATER MANAGEMENT IN SLOVENIA IN THE FRAME OF VULNERABILITY MAPPING
}

\author{
UPRAVLJANJE S KRAŠKIMI VODAMI V SLOVENIJI \\ V OKVIRU KARTIRANJA OBČUTLJIVOSTI
}

\author{
Nataša RAVBAR ${ }^{1}$, Gregor KOVAČIČ ${ }^{2}$
}

\begin{abstract}
UDC 556.3:65.012(497.4)

556.3:504.06(497.4)

Nataša Ravbar \& Gregor Kovačič: Karst water management in Slovenia in the frame of vulnerability mapping

Slovene karst sources are of great national importance for drinking water supply. Since karst aquifer systems are very susceptible to contamination, these sources require appropriate and careful managing. Unfortunately, in the acts of Slovene legislation, the special characteristics of water flow within karst regions are not very seriously taken into consideration in determining the criteria for karst water sources protection. In contrast, in some other countries, the concept of groundwater vulnerability mapping has been successfully used for protection zoning and land use planning in karst. Regarding the differences between particular karst aquifer systems, data availability and economic resources, different methods of karst water vulnerability assessment and mapping have already been developed. Already these methods have been many times tested and implemented in different test sites worldwide.

However, experience in application using different methodologies for vulnerability mapping of karst aquifers is very modest in Slovenia. The present paper deals with potential methodological problems that might arise while applying the most commonly used methods for karst water vulnerability assessment to Slovene karst regions.
\end{abstract}

Key words: karst water management, karst sources protection, drinking water, vulnerability assessment and mapping, Slovenia.
Izvleček

UDK 556.3:65.012(497.4)

556.3:504.06(497.4)

Nataša Ravbar \& Gregor Kovačič: Upravljanje s kraškimi vodami v Sloveniji v okviru kartiranja občutljivosti

Kraški izviri so v Sloveniji izjemnega pomena za vodooskrbo. Ker so kraški vodonosniki zelo občutljivi na onesnaženje, kraški vodni viri zahtevajo primerno in previdno upravljanje. Na žalost pa posebne značilnosti pretakanja voda $\mathrm{v}$ kraških pokrajinah niso zadovoljivo upoštevane pri določevanju kriterijev za zavarovanje kraških virov znotraj slovenske zakonodaje. Nasprotno se v nekaterih drugih državah koncept kartiranja občutljivosti podtalnice uspešno uporablja pri določevanju vodovarstvenih pasov in načrtovanju rabe prostora na krasu. Upoštevajoč razlike med posameznimi kraškimi vodonosnimi sistemi, razlik v dostopnosti do podatkov in $\mathrm{v}$ ekonomskih zmožnostih so bile izdelane številne metode ocenjevanja in kartiranja občutljivosti kraške podtalnice, ki so bile tudi večkrat uporabljene in preizkušene na različnih testnih poligonih po svetu.

V Sloveniji so izkušnje pri aplikaciji različnih metod kartiranja občutljivosti kraških vodonosnikov zelo skromne. V članku so opisani potencialni metodološki problemi, s katerimi se lahko srečamo pri aplikaciji posameznih običajno uporabljanih metod ocenjevanja občutljivosti kraške podtalnice v Sloveniji. Ključne besede: upravljanje s kraškimi vodami, varovanje kraških izvirov, pitna voda, ocenjevanje in kartiranje občutljivosti, Slovenija.

\footnotetext{
${ }^{1}$ Karst Research Institute, ZRC SAZU, Titov trg 2, SI-6230 Postojna, Slovenia, e-mail: natasa.ravbar@zrc-sazu.si

${ }^{2}$ University of Primorska, Faculty of Humanities Koper, Glagoljaška 8, SI-6000 Koper, e-mail: gregor.kovacic@fhs-kp.si

Received / Prejeto: 15.09.2006
} 


\section{INTRODUCTION}

Groundwater from karst aquifers is becoming more and more valuable for drinking water supply. In many regions worldwide it forms the only available drinking water resource. About one quarter of the global population is supplied by karst waters (Goldscheider 2002), while in some Alpine countries karst water contributes up to $50 \%$ of needs. In the case of Slovenia this amount reaches 43\% (Brečko Grubar \& Plut 2001). Extensive areas on the western, south-western, southern and southeastern parts of Slovenia are almost entirely dependent on karst water sources (Fig. 1). Therefore karst aquifers are becoming more and more strategically important and should be appropriately and carefully managed.

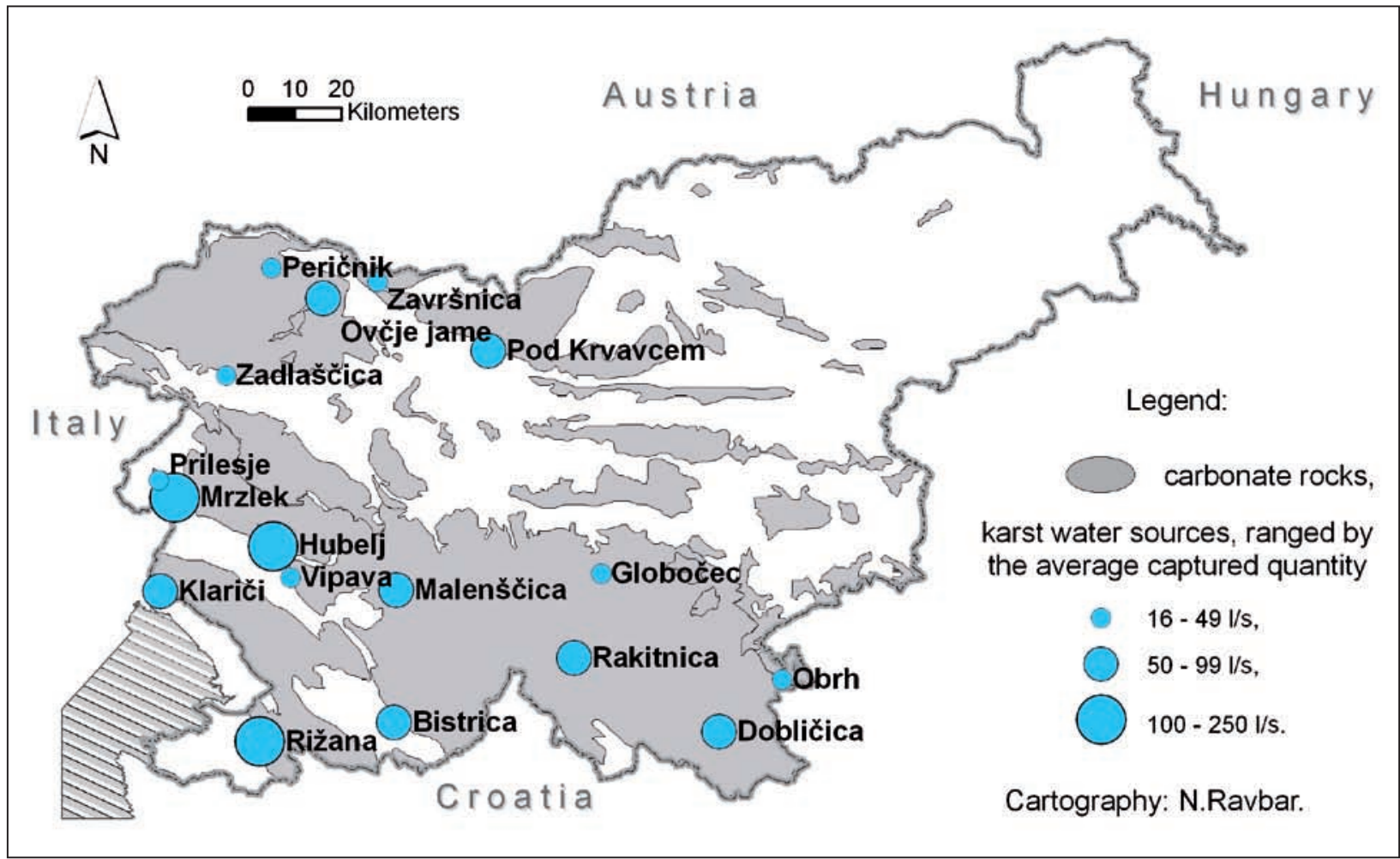

Fig. 1: The map shows the carbonate rocks extension and the most important karst water sources in Slovenia.

Sl. 1: Karta prikazuje razširjenost karbonatnih kamnin in najpomembnejše kraške vodne vire v Sloveniji.

The wide areas of karst regions in Slovenia are either uninhabited or scarcely populated with almost no agricultural activities or only with traditional ones, which is very favourable for water protection. Therefore, the karst aquifers are often considered as an abundant high-quality drinking water resource, though they are very vulnerable to pollution and should be managed and protected on a sustainable basis. Unfortunately, in the acts of Slovene legislation, the special characteristics of water flow within karst regions are not very seriously taken into consideration of determining the criteria for karst water sources protection. Furthermore, experience of karst aquifer protection within the frame of vulnerability assessment and mapping is very limited in Slovenia and more effort should be given to this subject in the future.

\section{KARST WATER PROTECTION IN SLOVENIA}

Important karst aquifers in Slovenia are mainly remote and uninhabited areas. The quality of karst groundwater, in general, is still relatively high, though some signs of contamination have already been recorded in some of the 
springs (Kovačič \& Ravbar 2005). Since the water protection reflects in land-use restrictions, the protection of karst water resources is often neglected in land-use management. Even where the water protection zones and regimes are established, the implementation of regulations is usually not effective and the control over polluters is weak. The example of the Bistrica karst spring illustrates some problems of water management in the area of an uninhabited Snežnik karst plateau (NW Dinarids), where sufficient protection zones have not yet been set up and water protection regulations have not been implemented properly (Kovačič 2003a).

Despite relatively favourable conditions for karst water sources protection in Slovenia compared to some other karst areas worldwide, many of the karst water sources still remain insufficiently protected.

\section{LEGISLATIVE FRAMEWORK}

Basic legislative provisions concerning karst groundwater protection policy in Slovenia are based on Waters Act 2002. Pursuant to the abovementioned Act it is government's responsibility to establish water protection areas and regimes in karst areas with respective drinking water sources and to ensure the implementation of the provisions in each protection zone.

According to the Rules on criteria for the designation of a water protection zone 2004, the hydrological background (i.e. protection area) of a specific captured karst spring or well should be divided in three basic protection zones. The outer zone coincides with the boundaries of the entire catchment area, while the first zone is determined on the basis of transfer time of flow shorter than $12 \mathrm{~h}$. Regarding the abovementioned Rules, the boundaries of water protection zones of karst aquifers should be determined on the basis of data on the velocities of karst groundwater, directions of groundwater flow, depth of water table, attenuation of actual and potential pollutants, chemical characteristics of karst groundwater and the extent and karstification degree of hydrological background. The Rules (2004) recommend several different methodologies for gathering the data. Carrying out a tracer test in the catchment area of a specific spring is not an obligatory one, though it is authors' opinion that it is one of the most appropriate hydrological methods that gives results on the underground flow paths, hydraulic properties of the aquifer and a helpful tool to delineate the catchment area of the particular water source. Such a configuration of legislation, unfortunately, lets the possibility of less accurate delineation of particular water protection zones. The concept of intrinsic vulnerability assessment and mapping is not directly included in the methodology described in the Rules.

\section{PRESENT SITUATION AND PROBLEMS}

Since the new Waters Act 2002 has been in force only for a relatively short period, majority of the karst sources are still protected in accordance with old legislation. According to the old Waters Act of 1981 the designation of water protection areas fell within the responsibility of local communities. Thus adequate protection was hindered by administrative borders between these communities. Due to the conflicts of interest in land use planning between neighbouring municipalities, protection zone extending over a territory of another municipality has usually not been accepted and the protection regime not established. In the case of the Rižana karst springs, which are tapped for the water supply of the Slovene coastal region, most of the second water protection zone extends over the neighbouring municipalities and even over the neighbouring country (Croatia) and hence is not protected (Kovačič 2003a). As with the Rižana karst springs, for the same reasons many other springs like the Malenščica and the Globečec springs are not suitably protected as well. The Malenščica spring is an important and the only source of drinking water supplying 20,000 inhabitants and economy of the Postojna and Pivka municipalities. Even though the water protection zones have been delineated and the necessary provisions defined two decades ago (Habič, 1987), the required decrees have not been accepted due to the conflicting interests in land use.

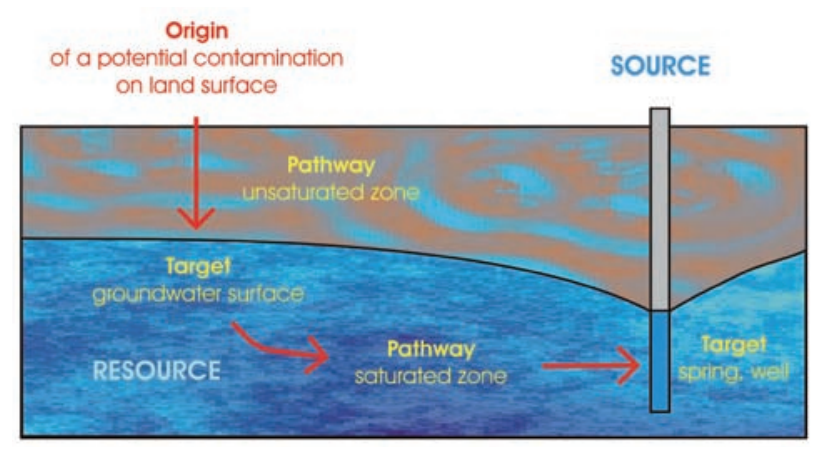

Fig. 2: Illustration of the origin-pathway-target model and the concept of the resource and source protection (after Goldscheider 2005).

Sl. 2: Ilustracija modela izvor-pot-cilj ter koncept zaščite vodnega vira in podtalnice (po Goldscheider 2005).

The Globočec spring is a regionally significant water source, but only protected in the administrative area of one municipality even though more than half of its influential area extends also to the neighbouring administrative areas (Ravbar 2005).

Since different approaches for the designation of water protection zones have been in use in Slovenia in past decades (Breznik 1976; Rismal 1993; Petauer \& Veselič 
1997), this has resulted in non-comparable water protection areas and regimes of different karst water sources, which is rather problematic for sufficient land-use planning in karst areas (Prestor 2002). Common characteristics of all three approaches are the transfer time delineation criteria, which define different water protection zones, and the division of hydrological background in three basic water protection zones. However, they differ markedly in their method for the determining the extent of individual protection zone, using different parameters. Due to the lack of sufficient data, the individual water protection zones were often not established on a solid hydrogeological basis, and were thus based only on available information on the geological structure. Nevertheless, for proper protection sufficient studies on source recharge, tracer tests in their catchments and other hydrological surveys are needed. Thus such protection zones are often insufficient and may be ineffective.

Nowadays situation in the field of karst water protection management in Slovenia is, unfortunately, more or less a reflection of an old legislation. Since the protection of karst aquifers fell within the responsibility of the government, establishment of karst water protection areas is now not any more hindered by the conflicts between land use and the demands for water protection on a local scale. Not many previously established water protection zones have been recently adapted to the new legislation. Thus some inadequately designated water protection zones are still valid. One of the most unfavourable consequences of unregulated conditions in the field of water protection legislation is that there is practically still no control over potential and actual polluters of karst groundwater.

The concept of karst water protection is still based only on the transfer time from the point of infiltration to the point of outflow (spring or well). Nevertheless, evaluation of different flow velocities (contamination transport times) in a sense of water protection and spatial distribution of different values of flow velocities within the background of an outflow is rather challenging. The characterization of flow and solute (contaminant) transport mechanisms in heterogenous karst aquifers (e. g. different values for diffuse and point recharge) could meet several problems, as well.

Nevertheless, crucial criteria for karst sources protection zones delineation are groundwater velocities. Where groundwater flow velocities are high, protection zones would cover large areas, often the entire catchment. However, it is impossible to require a high protection for large areas. Such spatial planning would be unreasonable and not practical. Above all, in areas with great market value of the land, rigorous land use restrictions would be controversial (Ravbar 2006).

Furthermore, groundwater velocities are not the only crucial aspects to determine higher/lower susceptibility of karst groundwater to contamination. Some other factors affecting the natural attenuation capacity of karst aquifers (e.g. function of protective cover, concentration of flow, karstification rate) are of at least the same importance, but are still not properly included in the karst water protection legislation in Slovenia.

\section{VULNERABILITY MAPPING AS AN ALTERNATIVE CONCEPT}

The concept of groundwater vulnerability mapping is an alternative approach for successful protection zoning delineation and land use planning in karst. The concept of groundwater vulnerability indicates the liability of a hydrologic system to contamination, using different colours to symbolize different degrees of vulnerability. The fundamental idea is to show that the protection provided by the natural environment varies at different locations (Vrba \& Zaporozec 1994). As a result the most vulnerable areas can be identified, and consequently at least those can be protected. However, this concept is not restricted to karst, but is most relevant when applied to karst landscapes (Goldscheider 2005).

Regarding the differences between particular karst aquifer systems, data availability and economic resources, different methods on karst water vulnerability assessment and mapping have been developed. In addition, these have been many times tested and implemented in different test sites worldwide. The existing methods take into account a variety of factors that control the infiltration of water and contaminants from the land surface towards the groundwater, such as overlying layers, infiltration conditions, degree of karstification and precipitation regime.

The first existing method with special consideration to karst aquifers was the EPIK method (Doerfliger \& Zwahlen 1998), which strongly influenced the later methods. Quite a few of the lately developed methods are based on the work undertaken by the COST Action 620 that developed the European Approach (Zwahlen 2004), a conceptual framework for karst groundwater intrinsic vulnerability assessment and mapping. Individual groups and individuals within the COST Action 620 have taken this approach as the basis for the particular methodology development. The European 
Approach takes into consideration four parameters (overlaying layers, concentration of flow, karst network development and precipitation regime).

A significant influence to the European Approach came from the previously developed PI method (Goldscheider 2002). It is based on an origin-target-pathway model. The origin is the term used to describe the location of a contaminant release. The term pathway is a flow path of a contaminant from the point of release (origin) to the target, which may be the groundwater surface or a drinking water abstraction point e.g. spring or well (Daly et al., 2002; Goldscheider 2005). There are two general approaches of a water protection: resource protection aims to protect the whole groundwater body and source protection that aims to protect a particular spring or well.
In some of the countries respective vulnerability mapping approaches have also been integrated in the states legislation e.g the Irish Method in Ireland (GSI 1999), the SINTACS method in Italy (Cività \& De Maio 1997). The EPIK method (Doerfliger \& Zwahlen 1998) has been integrated in Swiss legislation only for karst sources. The GLA method (Hölting et al., 1995) is a supplement to the German groundwater protection schemes.

However, in Slovenia experiences of such application are very modest. Only two karst spring vulnerability studies have been done so far; Janža \& Prestor (2002) using the SINTACS and Petrič \& Šebela (2004) using the EPIK method.

\section{METHODOLOGICAL PROBLEMS AND SPECIFICS OF KARST AQUIFER VULNERABILITY ASSESSMENT AND MAPPING IN SLOVENIA}

\section{GENERAL CHARACTERISTICS OF SLOVENE KARST LANDSCAPES}

Direct application of some existing vulnerability mapping methods could meet several difficulties first of all due to the specific characteristics of the Slovene karst. In Slovenia karst regions extend over $43 \%$ of the country, spreading from the Karavanke range and the plateaus of the Julian and Kamniške-Savinjske Alps at an altitude of $2500 \mathrm{~m}$ to the shore of the Mediterranean Sea and Dinaric karst on the south. Large karst massifs and karst plateaus, intersected by shallow karst areas, karst poljes and valleys, characterize these landscapes. Thick sequences of very pure and deeply karstified limestones and dolomites of the Mesozoic era prevail. The depth of the unsaturated zone can reach several hundreds of meters, in the mountain massifs even $1500 \mathrm{~m}$ and more. Carbonate rocks are of very good to medium permeability, the groundwater flow velocities are ranging between 0.02 and $29.6 \mathrm{~cm} / \mathrm{s}$, respectively from $0.72 \mathrm{~m} / \mathrm{h}$ to $1065.6 \mathrm{~m} / \mathrm{h}$ (Novak 1993).

Less permeable or impermeable deposits traversing karst areas, border karst aquifers and prevent the underground runoff; so do flysch and less permeable dolomite layers caused by folding and thrusting. Slovene karst landscapes are strongly tectonically modified. Fault zones that intersect or border karst areas can act as hydrological barrier as well. Consequently, karst underground water emerges to the surface through numerous efficacious springs at the aquifers edges.

Catchment areas of most of them are very complex, covering karst and non-karst areas as well. Catchments often extend over several tens or even hundreds $\mathrm{km}^{2}$ and are hydraulically connected over long distances. Watersheds are often overlapping and the flow paths proved by tracer tests often cross each other. Furthermore, it is practically impossible to define the position of individual springs' watersheds, precisely due to their high variability in time and strong dependence on the respective hydrologic conditions. Namely, in dependence on the respective hydrologic conditions in several karst areas frequent and very high groundwater fluctuations appear (several tens up to few hundred meters). Consequently, also variable flow velocities, changing flow directions and surface-underground flow interactions result.

Very thin or mostly absent protective soil cover and common absence of other protective overlaying layers, such as subsoil and non-karst rocks is significant. The average annual precipitation amounts ranges from 1000 up to $4000 \mathrm{~mm}$ in the mountainous areas.

\section{METHODOLOGICAL PROBLEMS AND OPEN QUESTIONS}

Regarding the peculiarity of individual intrinsic vulnerability mapping methods, the adequacy of the criteria such as parameter selection and the method of parameter weighting, different difficulties might arise when applying a particular method to Slovene karst.

In many of the existing methods the characteristics of the layers lying above the saturated zone are the most important factor controlling natural protection of groundwater against contamination (self-cleaning or carrying capacity). Some among the methods provide assessment schemes, where protective function assess- 
ment consists of up to four layers of the unsaturated zone (topsoil, subsoil, non-karst rocks and karst rocks). Such a very detailed system of protective function assessment requires a vast amount of data, which is a special problem in Slovenia, discussed below. The assessment of the overlying layers protective function has been shown to be one of the major problems in one of the previous applications as well (Janža \& Prestor 2002).

Because of the common absence of soil and/or sediment cover in Slovene karst, the protective function value would mainly be influenced by the depth of the unsaturated zone. Due to the enormous thickness of the unsaturated zone, the protective values would often be classified as "moderate", not showing the vulnerability differences within the aquifer itself. Therefore, the selection of only two parameters (soil and lithological characteristics of the unsaturated zone) together with a not very detailed system of protective function assessment could be suitable as well (Fig. 3).

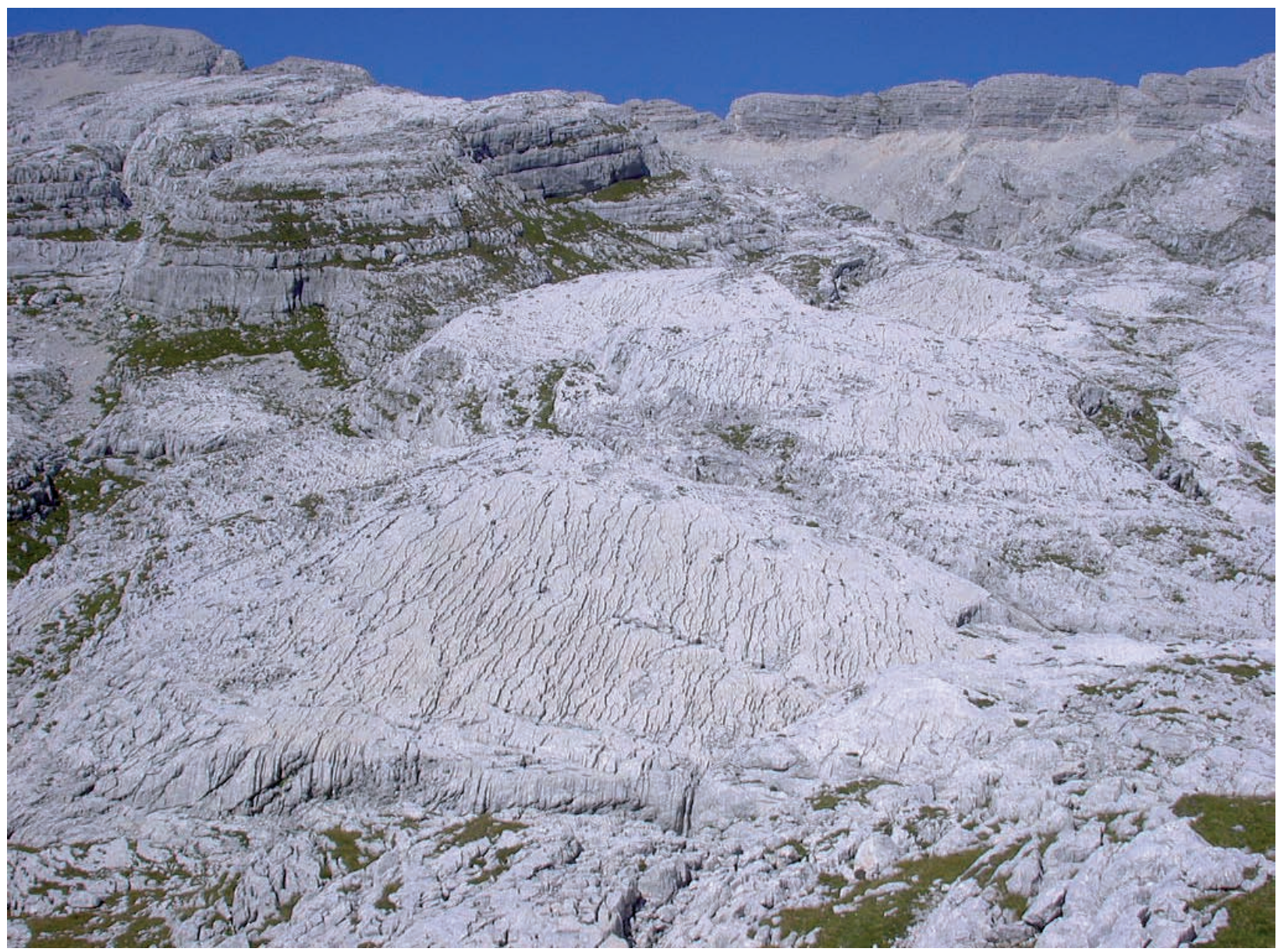

Fig. 3: An example of a bare karst surface on Kanin high mountain plateau $(2587 \mathrm{~m})$, where the depth of the unsaturated zone exceeds 1500 m (photo: G. Kovačič).

Sl. 3: Primer golega kraškega površja na visoki kraški planoti Kanin $(2587 \mathrm{~m}$ ), kjer je debelina nezasičene cone večja od $1500 \mathrm{~m}$ (foto: G. Kovačič).

There is a problem in assessing a hydrological function of epikarst, where storage of water and concentration of flow occur. The first process increases the natural protection of karst aquifer, while the latter increases vulnerability of the karst system. The problem of epikarst is that its existence is not always easily recognizable by the surface karst features. Furthermore, great spatial differences of its development on short distances are present due to heterogeneity of karst landscapes (Kovačič 2003b). The concept of mapping surface karst features indicating the existence of different tectonically crushed zones within karst aquifer and consequently the occurrence of more or less developed epikarst zones was successfully introduced by Petrič \& Šebela (2004).

Furthermore, there is still a question how to consider areas with great groundwater level oscillations, where 
groundwater level varies for several tens or even hundreds of meters in a short time and causes great change of drainage divides and flow directions. The protectiveness of the unsaturated zone in highly karstified rocks is generally considered to be fairly low. Variable thickness of this zone would consequently have limited impact on final vulnerability value. However, groundwater level fluctuations might alter catchment boundaries, which is crucial for source vulnerability mapping and should therefore be additionally considered (Ravbar \& Goldscheider, in press).

Due to great groundwater level oscillations, some karst landscapes in Slovenia are also characterised by surface and groundwater flow alteration that is relevant with respect to groundwater vulnerability (Figs. $4 \& 5$ ). Intermittent river flows and lakes, some of which appear several times per year, while others occur only very ex- rainfall" conditions that occur several times per year (Goldscheider 2002). The degree of vulnerability of the area characterised by surface and groundwater flow alteration may vary drastically in dependence on respective hydrologic conditions. Therefore, when making vulnerability maps, a distinction should be made between zones of concentrated infiltration that are permanently drained into swallow holes and those that are only occasionally drained into karst.

In the vulnerability assessment, special emphasis must be given on the function of the sinking rivers, which occur within karst poljes or recharge in non-karst areas and sink on the contact with carbonates. The latter can have either huge or small catchments, which has to be considered in vulnerability assessment, since swallow holes are points of concentration of flow, causing fast infiltration of surface waters and contaminants towards

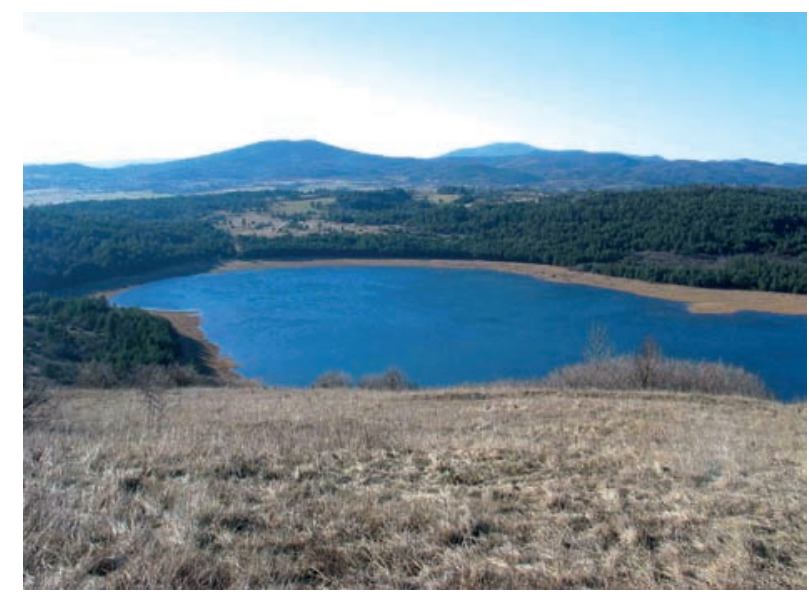

Fig. 4 and 5: The intermittent lake Petelinjsko jezero is flooded up to six months per year. At low groundwater level a shallow karst depression is dry (left), while at high groundwater level it is flooded and forms a lake (right). The degree of vulnerability of the area may vary drastically depending on respective hydrologic conditions (photo: N. Ravbar).

Sl. 4 in 5: Presihajoče Petelinjsko jezero je poplavljeno do šest mesecev na leto. Ob nizkem vodostaju je kraška depresija suha (levo), medtem ko je od visokih vodah poplavljena in spremenjena $v$ jezero (desno). V odvisnosti od trenutnih hidroloških pogojev se lahko stopnja občutljivosti na tem obmoćju izrazito razlikuje (foto: N. Ravbar).

ceptionally, as well as temporary springs, swallow holes and estavelles are significant. Consequently only in a case when a water body (river, lake) is frequently or permanently sinking into karst, a contaminant release would always and rapidly reach the groundwater without significant attenuation. On the other hand, a contaminant transport and its attenuation capacities might vary drastically where there are no temporary or perennial water flow conditions (Ravbar \& Goldscheider, in press).

So far the existing methods do not provide sufficient tools to cope with hydrologic variability. The EPIK method takes into account temporary or perennial water flow conditions (Doerfliger \& Zwahlen 1998). Similarly the PI method takes into consideration "average storm the groundwater. A question arises, how to delineate the influence area of such surface flow on karst aquifer, since the surface flows have their own self-cleaning capacities (Kovačič 2003b).

Furthermore, Slovene legislation demands individual water source protection. Nevertheless, resembling some European countries, no resource protection policy has been provided so far. For source vulnerability assessment where captured springs and wells are the targets (see the origin-pathway-target model above), the additional horizontal flow path in the saturated zone, the so-called $\mathrm{K}$ factor, has to be considered. So far only the EPIK method provided tools for the $\mathrm{K}$ factor assessment. The European Approach is foreseeing incorporation of 
the $\mathrm{K}$ factor into the vulnerability assessment as well, but does not specify how it should be measured or categorized. Therefore in many cases an additional step from resource to source vulnerability mapping should be done if we would like an application to be adequate to Slovene legislation.

When applying the SINTACS method Janža and Prestor (2002) added an extra criterion of cave density for implementing the unsaturated zone attenuation capacity and hydraulic conductivity range of aquifer into the proposed method. However, the information on cave density is not relevant criterion for the karstification degree assessment as it can reflect the degree of research work in a certain area. Furthermore, size, connection and density of karst conduits or caves are often results of previous climate conditions. In general, the conduit size aspect cannot be acceptable criteria, because even a relatively small degree of karstification (e.g. conduits 10 $\mathrm{cm}$ wide) can result in very high travel times and very rapid contaminant transport without significant attenuation. On the contrary, for the mostly horizontal pathway through the saturated karst bedrock to the source, the groundwater flow characteristics and distance to the source have to be considered.

The European Approach considers also the assessment of the $\mathrm{P}$ (precipitation regime) factor, which modifies other parameters and thus the final assessment of vulnerability as well. Some of the methods (SINTACS, PI and COP) have already introduced the precipitation characteristics into their schemes. The question is, whether it is practical to assess the value of precipitation regime within the small area of the same aquifer, since it is not very likely that the differences in intensity and amounts of precipitation vary significantly between particular parts of a catchment and thus not essentially influence its vulnerability. However, it has already been shown that when applying the COP method in many different aquifers across Europe, the $P$ factor itself has small correlation with the final vulnerability values and shows important differences only when the method is applied to the aquifers with different climate characteristics (Vías et al., 2006).

Nevertheless, if introducing the P factor it would be recommendable to consider the effective infiltration instead, since it presents the true amount of water infiltrating into the subsurface. Furthermore, higher vulnerability (i.e. higher transport velocities, shorter transit time, more turbulent flow, more effective transport of sediments and bacteria, mobilisation of DNAPL - Dense Non-Aqueous Phase Liquid, more surface flow etc.) does not only depend on the actual amount of water infiltrating into the subsurface but also on the previous soil and epikarst zone water saturation.
However, there is a methodological problem, how to evaluate the protective function of a P factor as well. Do the greater amounts of infiltrating water increase the vulnerability of a karst system (faster contaminant wash-off, shorter transfer time - less time for appropriate intervention) or do they contribute to the groundwater protection (dilution, faster reduction of contaminants' concentrations, shorter duration of contamination)?

As mentioned before, in Slovene karst many areas drain into several abundant springs at the aquifers margins. In case of springs' watersheds overlapping, vulnerability maps of different sources might show different values of vulnerability due to respective springs. This raises a question, which source vulnerability map/value should be considered as more important. In terms of protection degree and spatial planning, the highest degree of vulnerability should be considered. However, when planning the implementation of sanitary provisions in water protection zones, also an additional parameter indicating the economic and/or social importance of a particular water source should be considered.

Accurate and detailed studies are essential for vulnerability assessment. Several problems are expected and have also been confirmed while applying some of the existing vulnerability mapping methods in Slovene karst landscapes due to poor database, data availability and assessment. If the method requires very large amount of detail data, it does not only makes vulnerability assessment more expensive, but also makes the application less flexible and often unsuitable, as very rarely is a large amount of data available. Particularly scarce are data in remote and mountainous karst areas.

In addition, methods that require grid input information (e.g. the SINTACS method) are not very appropriate for the application in karst areas, since the karst aquifers are very heterogenous systems characterised by great and inherent changes in small area. 


\section{CONCLUSION}

In Slovenia karst aquifers are of special economic importance. Even though the quality of the groundwater is still relatively high, some sources of contamination have already been recorded, showing the shortcomings of water management even in the uninhabited alpine karst areas, which are ordinarily very favourable for water protection (Kovačič \& Ravbar 2005).

In order to protect the quality and quantity of water sources and resources for future generations the concept of groundwater vulnerability mapping and assessment has been in the past decades more and more coming to the fore. Assessment of groundwater vulnerability evaluates the intrinsic characteristics of the aquifer systems and subdivides an area into several units showing different degrees of natural protection. It provides a useful conceptual framework, which could be the basis for the water protection zones and regimes establishment (Vrba \& Zaporozec 1994).

Nowadays various methodologies are in use, among which also methods with special consideration of karst aquifers have been introduced. However, experiences on application using methods for vulnerability mapping of karst aquifers are very limited in Slovenia.

In future, application of some of the most commonly used methods should be stimulated in order to subject eventual methodological problems that may arise during the application. Comparison of different methods in a single test site is therefore advisable. Considering specific characteristics of Slovene karst (very thin or mostly absent protective cover, very complex and large catchment areas, lack of quality and representative research, poor database, problem of data availability, etc.) selection among the simplest methods would be reasonable. Methods that require very detailed data on protective cover characteristics or require very thorough database on catchment area should thus be avoided.

Eventually, according to adequacy of particular criteria, such as parameter selection, parameter weighting and final assessment reckoning the most satisfactory among the existing methods should be selected and improved if necessary. To propose a common method for karst water source vulnerability mapping its validation using hydrological and statistical methods is essential.

Finally, a common method, which would be the basis for the water protection zones and regimes establishment, could be used for resource protection and land use planning in karst aquifers. Furthermore, it could be a supplement to the existing legislation for karst sources protection.

According to the Rules (2004), the main criterion for the delineation of the source protection zones is the travel time of groundwater in the aquifer. However, a vulnerability assessment and mapping could be an additional criterion for karst sources protection. It could present a supplement for reduction and/or enlargement in the size of the zones where necessary according to the intrinsic properties of a particular catchment area.

Furthermore, source and resource maps could be practical tool for future land use management, spatial planning of human activities and for the sanitary provisions planning in water protection zones as well.

\section{REFERENCES}

Brečko Gruber, V. \& D. Plut, 2001: Kakovost virov pitne vode v Sloveniji.- Ujma, 14-15, 238-244, Ljubljana.

Breznik, M., 1976: Metodologija zaščite podzemne pitne vode ter določitve varstvenih območij in pasov. Regionalni prostorski plan RS 3/4. Zasnove uporabe prostora. Vodno gospodarstvo Ljubljana, Zavod SRS za družbeno planiranje, $176 \mathrm{p}$.

Cività, M. \& M. De Maio, 1997: SINTACS: Un sistema parametrico per la valutazione e la cartografia della vulnerabilita degli acquiferi all'inquinamento. Metodologia \& automatizzazione. Pitagora Editrice, 208 p., Bologna.
Daly, D., Dassargues, A., Drew, D., Dunne, S., Goldscheider N., Neale, S., Popescu, I.C. \& F. Zwahlen, 2002: Main concepts of the »European approach" to karst-groundwater-vulnerability assessment and mapping.- Hydrogeology Journal, 10, 340-345.

Doerfliger, N. \& F. Zwahlen, 1998: Practical Guide, Groundwater Vulnerability Mapping in Karstic Regions (EPIK). Swiss Agency for the Environment, Forests and Landscape (SAEFL), 56 p., Bern.

Goldscheider, N., 2002: Hydrogeology and vulnerability of karst systems - examples from the Northern Alps and Swabian Alb.- PhD Thesis. University of Karlsruhe, Faculty for Bio- and Geoscience, 236 p., Karlsruhe. 
Goldscheider, N., 2005: Karst groundwater vulnerability mapping: application of a new method in the Swabian Alb, Germany.- Hydrogeology Journal, 13, 555-564.

GSI (1999): Groundwater protection schemes. Geological Survey of Ireland, $24 \mathrm{p}$.

Habič, P., 1987: Raziskave kraških izvirov v Malnih pri Planini in zaledja vodnih virov v občini Postojna.Tipkano poročilo, 58 p., Archive Karst Research Institute SRC SASA, Postojna.

Hölting, B., Haertlé, T., Hohberger, K. H., Nachtigall, K. H., Villinger, E., Weinzierl, W. \& J. P. Wrobel, 1995: Konzept zur Ermittlung der Schutzfunkzion der Grundwasserüberdeckung.- Geol. Jb., C63, 5-20.

Janža, M. \& J. Prestor, 2002: Ocena naravne ranljivosti vodonosnika v zaledju izvira Rižane po metodi SINTACS.- Geologija, 45/2, 401-406, Ljubljana.

Kovačič, G., 2003a: The protection of karst aquifers: the example of the Bistrica karst spring (SW Slovenia).Acta Carsologica, 32/2, 219-234, Ljubljana.

Kovačič, G., 2003b: Parametrične metode kartiranja občutljivosti kraških vodonosnikov - pregled, primerjava in kritika.- Seminarska naloga. Univerza na Primorskem, Fakulteta za humanistične študije, 77 p., Ilirska Bistrica.

Kovačič, G. \& N. Ravbar, 2005: A review of the potential and actual sources of pollution to groundwater in selected karst areas in Slovenia.- Natural Hazards and Earth Systems Science, 5/2, 225-233.

Novak, D., 1993: Hydrogeological research of the Slovenian karst.- Naše jame, 35, 1, 15-20, Ljubljana.

Petauer, D. \& M. Veselič, 1997: Metodologija določevanja zaščitenih območij podzemnih voda. Ministrstvo za okolje in prostor, 13 p., Ljubljana.

Petrič, M. \& S. Šebela, 2004: Vulnerability mapping in the recharge area of the Korentan spring, Slovenia.Acta Carsologica, 33/2, 151-168, Ljubljana.

Prestor, J., 2002: Problematika določanja varstvenih pasov in razporeditve ukrepov za zaščito vodnih virov.- Zbornik seminarjev Varstvo in kvaliteta pitne vode, Inštitut za sanitarno inženirstvo, 69-77.

Ravbar, N., 2005: Spill of dangerous substances in the catchment area of the Globočec karst spring, SE Slovenia.- In: Stevanović, Z., Milanović, P. (Eds.) Water resources and environmental problems in karst, 193-200, Belgrade.
Ravbar, N., 2006: The protection of karst water sources in Slovenia.- In: Duran, J. J., Andreo, B. \& F. Carrasco (Eds.). Congreso Internacional sobre el agua subterranea en los paises Mediterraneos. Karst, climate change and groundwater, 231-237, Malaga.

Ravbar, N. \& N. Goldscheider, (in press): Integrating temporal hydrologic variations into karst groundwater vulnerability mapping - examples from Slovenia.- $8^{\text {th }}$ Conference on Limestone Hydrogeology, Neuchâtel.

Rismal, M., 1993: Zaščita podtalnice - Strokovno navodilo za izdelavo normativnih aktov za zavarovanje kakovosti podtalnice, FAGG, Ljubljana.

Rules on criteria for the designation of a water protection zone. 2004: Official Gazette of the Republic of Slovenia, 64, 8111-8128.

Vías, J. M., Andreo, B., Neukum, C. \& H. Hötzl, 2006: Aplicación del método COP para la evaluación de la vulnerabilidad del aquífero carboná tico de Bauschlotter Platte (Alemania). Comparación de resultados con otros aquíferos del sur de España.- In: Duran, J. J., Andreo, B. \& F. Carrasco (Eds.). Congreso Internacional sobre el agua subterranea en los paises Mediterraneos. Karst, climate change and groundwater, 249-256, Malaga.

Vrba, J. \& A. Zaporozec, (Eds.) 1994: Guidebook on mapping groundwater vulnerability.- International association of hydrogeologists. Verlag Hienz Heise, Vol. 16, 131 p., Hannover.

Waters Act. 1981: Official Gazette of the Republic of Slovenia, 38, 2308-2320.

Waters Act. 2002: Official Gazette of the Republic of Slovenia, 67, 7648-7680.

Zwahlen, F., 2004: Vulnerability and Risk Mapping for the Protection of Carbonate (Karstic) Aquifers. Final report COST action 620.- European Commission, Directorate-General for Research, 297 p., Brüssel, Luxemburg. 